\title{
Interactive Effects of Copper on Alfalfa Growth, Soil Copper, and Soil Bacteria
}

\author{
James A. Ippolito (Corresponding author) \\ USDA-ARS Northwest Irrigation and Soils Research Laboratory \\ 3793N 3600E, Kimberly, ID, 83341, Idaho \\ Tel: 1-208-423-6524Ｅ-mail: jim.ippolito@ars.usda.gov \\ Tom F. Ducey \\ USDA-ARS Coastal Plains Soil, Water, and Plant Research Center \\ 2611 W. Lucas St., Florence, SC, 29501, South Carolina \\ Tel: 1-843-669-5203 ext. 112 E-mail: thomas.ducey@ars.usda.gov \\ David D. Tarkalson \\ USDA-ARS Northwest Irrigation and Soils Research Laboratory \\ 3793N 3600E, Kimberly, ID, 83341, Idaho \\ Tel: 1-208-423-6503Ｅ-mail: david.tarkalson@ars.usda.gov
}

Received: September 30, $2010 \quad$ Accepted: October 15, 2010 doi:10.5539/jas.v3n2p138

\begin{abstract}
Copper sulfate $\left(\mathrm{CuSO}_{4}\right)$ foot baths are a management practice used by dairy farms in an effort to control hoof infections. As an unintended consequence, agricultural soils experience $\mathrm{Cu}$ accumulation when spent foot baths are disposed of in wastewater lagoons utilized for irrigation purposes. We investigated the effect of $\mathrm{Cu}$ applications (up to $1000 \mathrm{mg} \mathrm{kg}^{-1}$ ) to a Xeric Haplocalcid (Declo series) and a Typic Calciaquoll (Logan series) on alfalfa (Medicago sativa) growth and $\mathrm{Cu}$ concentration, soil total and diethylenetriaminepentaacetic acid (DTPA)-extractable $\mathrm{Cu}$, and the soil bacterial community diversity using ribosomal intergenic spacer analysis (RISA). Copper application up to $250 \mathrm{mg} \mathrm{kg}^{-1}$ did not affect alfalfa growth; above $500 \mathrm{mg} \mathrm{Cu} \mathrm{kg}^{-1}$ alfalfa did not grow. Increasing $\mathrm{Cu}$ application rates increased alfalfa $\mathrm{Cu}$ content grown in both soils. Regardless of initial application rate, 48 to $80 \%$ of the added $\mathrm{Cu}$ was still plant-available at the end of the study. Comparing DTPA-extractable $\mathrm{Cu}$ to alfalfa $\mathrm{Cu}$ concentrations, 63 or $95 \mathrm{mg} \mathrm{kg}^{-1}$ of DTPA-extractable soil $\mathrm{Cu}$ for the Declo and Logan soils, respectively, would be detrimental in terms of cattle dietary $\mathrm{Cu}$ intake. For Declo soils, bacterial diversity remained relatively stable across all $\mathrm{Cu}$ application rates; Logan soils saw a peak in bacterial diversity at the $50 \mathrm{mg} \mathrm{kg}^{-1} \mathrm{Cu}$ application rate. Cluster analysis revealed differences in the bacterial RISA profiles between the lower and higher $\mathrm{Cu}$ application rates. To prevent excessive alfalfa $\mathrm{Cu}$ accumulation and negative impacts on the soil bacterial community, it is suggested available soil $\mathrm{Cu}$ not exceed $63 \mathrm{mg} \mathrm{kg}^{-1}$ in agroecosystems associated with these soil series.
\end{abstract}

Keywords: Alfalfa, Cattle wastes, Soil copper, Soil bacteria

\section{Introduction}

Agricultural soil $\mathrm{Cu}$ accumulation can be a concern to producers receiving manure sources with elevated $\mathrm{Cu}$ concentrations. In particular, dairy operations utilize between 5 to $10 \%(\mathrm{w}: \mathrm{v}) \mathrm{CuSO}_{4}$ concentrations (equivalent to 12,500 to $25,000 \mathrm{mg} \mathrm{Cu} \mathrm{L}^{-1}$ ) in foot baths to control hoof infections, with spent foot baths typically washed out of dairy barns and into liquid waste lagoons. Once $\mathrm{CuSO}_{4}$ enters the waste lagoon the soluble $\mathrm{Cu}$ concentration decreases due to dilution and $\mathrm{Cu}$ binding to organic phases, which binds approximately 90 to $95 \%$ of the $\mathrm{Cu}$ (Stehouwer and Roth 2009). However, 625 to $2500 \mathrm{mg} \mathrm{Cu} \mathrm{L}^{-1}$, depending on initial foot bath $\mathrm{Cu}$ content, remains in a soluble form. Because excessive soluble soil $\mathrm{Cu}$ can be toxic to plants (Paschke and 
Redente 2002; White and Brown 2010), Cu-enriched liquid dairy waste applied as irrigation water to agricultural crops raises concerns regarding how plants and soils are impacted.

Soil $\mathrm{Cu}$ occurs in several forms: in the soil solution; on soil exchange sites; specifically sorbed; occluded in soil oxides; in the lattice structure of primary and secondary minerals; and in organic residues and living organisms (Adriano 1986). In soils with $\mathrm{pH}$ values greater than 7.0, such as those typical of arid regions, soluble $\mathrm{Cu}$ can react to form $\mathrm{CuO}, \mathrm{CuCO}_{3}$, or mixed hydroxy-carbonate mineral species (McBride and Bouldin 1984; Ponizovsky et al. 2007). However, in basic soils the majority of $\mathrm{Cu}$ is strongly adsorbed to soil organic matter $(\mathrm{OM})$ due to greater $\mathrm{OM}$ solubility and increasing $\mathrm{pH}$ dependent charge associated with increasing soil $\mathrm{pH}$ (McBride and Blasiak 1979). Copper complexation in calcareous soils has been shown to increase with increasing $\mathrm{OM}$ content, thus decreasing $\mathrm{Cu}$ availability to plants (Ghasemi-Fasaei et al. 2006).

Detrimental impact to plants due to $\mathrm{Cu}$ application above plant $\mathrm{Cu}$ requirements, regardless of potential soil precipitation or complexation reactions, has been observed. Copper mainly impairs root growth through inhibition of lateral root development and new seedling root growth initiation (Pahlsson 1989). Subsequently, plants tend to be stunted, chlorotic, or necrotic (Pierzynski et al. 2000). Brun et al. (2001) studied corn (Zea mays $\mathrm{cv}$. Gaucho) root and shoot growth when grown in Cu-contaminated vineyard soils (up to $251 \mathrm{mg}$ total $\mathrm{Cu} \mathrm{kg}^{-1}$ ). Root $\mathrm{Cu}$ concentrations ( 23 to $584 \mathrm{mg} \mathrm{kg}^{-1}$ ) were greater than shoot concentrations ( 7 to $17 \mathrm{mg} \mathrm{kg}^{-1}$ ), with total $\mathrm{Cu}$ and cation exchange capacity, and total $\mathrm{Cu}$, soil $\mathrm{pH}$, and $\mathrm{OM}$ explaining 81 and $85 \%$ of the variability in root and shoot $\mathrm{Cu}$ content, respectively. Sonmez et al. (2006) studied the effect of increasing concentrations $(0,1000$, $2000 \mathrm{mg} \mathrm{Cu} \mathrm{kg}^{-1}$ ) to tomato (Lycopersicon esculentum (L.) Mill. Cv. F144), observing a decrease in plant height, total yield, number of fruit, and dry root weight with increasing $\mathrm{Cu}$ application.

Not only are excessive $\mathrm{Cu}$ concentrations detrimental to plants, they may also toxic to microorganisms. Ranjard et al. (2006) investigated the effects of $\mathrm{Cu}\left(16\right.$ and $\left.48 \mathrm{~kg} \mathrm{ha}^{-1}\right)$ on indigenous soil microorganisms in a calcareous silty clay soil, showing that two months following $\mathrm{Cu}$ application the control soil bacterial and fungal populations were significantly different from Cu-treated soils regardless of application rate. Ranjard et al. (2006) carried the experiment out to four and twelve months following application, observing no difference between treatments and the control at both time steps. The authors suggested that a transitory effect of the $\mathrm{Cu}$ stress might be partly due to the progressive reduction of soil $\mathrm{Cu}$ bioavailability over time. Yet time does not always reduce bioavailability, as shown by Sauve (2006) who noted that soil OM degradation by microorganisms was inhibited by 10,20 , and $50 \%$ with 154,193 , and $285 \mathrm{mg} \mathrm{Cu} \mathrm{kg}^{-1}$ soil at a site exposed to decades of $\mathrm{Cu}$ contamination.

The $\mathrm{Cu}$ concern in Idaho is increasing because of rising dairy $\mathrm{CuSO}_{4}$ foot bath usage; Idaho is currently the third largest dairy producing state in the US ( 550,000 head of dairy cows; USDA NASS 2009$)$ with most of the dairy industry is located in south-central Idaho. Land application of $\mathrm{Cu}$, from spent foot baths, may detrimentally affect alfalfa raised for dairy cow feed. Thus, the main objectives of this pilot study were to quantify the effects of $\mathrm{Cu}$ addition on: 1) alfalfa growth; 2) soil total and subsequently extractable $\mathrm{Cu}$ characteristics; and 3) soil bacterial community structure and diversity. Soil extractable $\mathrm{Cu}$ concentrations were also used to determine an estimate of extractable soil $\mathrm{Cu}$ associated with alfalfa $\mathrm{Cu}$ content and the maximum tolerable $\mathrm{Cu}$ level in cattle feed based on National Research Council (2005) guidelines.

\section{Materials and Methods}

\subsection{Soils}

The Declo (loam; coarse-loamy, mixed, superactive, mesic Xeric Haplocalcid) and Logan (silty clay loam; fine-silty, mixed, superactive, mesic Typic Calciaquoll) soil series were utilized for this study as they are extensive in south-central Idaho (63,860 and 6,270 ha, respectively; USDA NRCS 2009). Surface soils (0-30 cm) were collected, air dried and passed through a $6.35-\mathrm{mm}$ sieve. A part of this material passed through a 2-mm sieve and analyzed for certain properties (Table 1) and the rest material was used for the pot experiment. Soil texture was determined by the hydrometer method (Gee and Or, 2002). Soil pH (Thomas 1996) and electrical conductivity (EC; Rhoades 1996) were determined on a saturated paste extract, and cation exchange capacity via the method outlined by Sumner and Miller (1996) for soils containing carbonates. Total C was determined using the dry combustion method outlined by Nelson and Sommers (1996), while $\mathrm{CaCO}_{3}$ and inorganic $\mathrm{C}$ content were determined by a modified pressure-calcimeter method (Sherrod et al. 2002); organic C was determined via difference between total $\mathrm{C}$ and inorganic $\mathrm{C}$, and $\mathrm{OM}$ was calculated by multiplying organic $\mathrm{C}$ content by 1.724. Nitrate- $\mathrm{N}$ and $\mathrm{NH}_{4}-\mathrm{N}$ were determined following methods outlined by Mulvaney (1996), Olsen-extractable $\mathrm{P}$ was determined as outlined by Kuo (1996), and total $\mathrm{Ca}, \mathrm{Mg}, \mathrm{Na}, \mathrm{K}, \mathrm{Fe}, \mathrm{P}, \mathrm{Mn}, \mathrm{Zn}, \mathrm{Mo}$, and $\mathrm{Cu}$ using a $4 \mathrm{M}$ $\mathrm{HNO}_{3}$ digest (Bradford et al. 1975). 


\subsection{Experimental Setup}

$1.5 \mathrm{~kg}$ of soil was placed into individual $23 \mathrm{~cm}$ tall $\mathrm{x} 10 \mathrm{~cm}$ diameter pots with no drain holes. All pots received $\mathrm{P}\left(\mathrm{KH}_{2} \mathrm{PO}_{4}\right.$ in liquid form) at a rate equivalent to $108 \mathrm{~kg} \mathrm{P} \mathrm{ha}^{-1}$ based on Olsen-extractable $\mathrm{P}$ and the University of Idaho fertilizer recommendations for alfalfa (Stark et al. 2002). Pots were brought to $70 \%$ of field capacity using tap water three times per week during the study period. Six alfalfa seeds were planted into each pot and allowed to establish over a 5 week period, after which plants were thinned to three per pot. Pots then received $\mathrm{Cu}$ solutions, as $\mathrm{CuSO}_{4}$, at concentrations of 0 (control), 50, 100, 250, 500, or $1000 \mathrm{mg} \mathrm{Cu} \mathrm{kg}$, and plants were allowed to grow for approximately three weeks. The experimental design was completely randomized with four replicates.

\subsection{Plant and Soil Chemical Analyses}

Pot cumulative evapotranspiration (ET) losses were calculated by summing daily gravimetric ET losses for the first 14 days following copper application. Live plants were harvested $\sim 2.54 \mathrm{~cm}$ above the soil surface 23 days after $\mathrm{Cu}$ was applied, placed in paper bags, oven dried at $60^{\circ} \mathrm{C}$ for 72 hours, biomass determined, and then ground to pass a 20 -mesh sieve. A 0.50 -g subsample was placed in a $100-\mathrm{mL}$ beaker and ashed at $500^{\circ} \mathrm{C}$ for 5 hours. The samples were allowed to cool, weighed, and then $10 \mathrm{~mL}$ of $1 M \mathrm{HNO}_{3}$ was added. The samples were then heated on a hot plate until condensation no longer occurred on the inside of the beaker. Then, all samples were brought to a $50 \mathrm{~mL}$ final volume by weight with de-ionized $\mathrm{H}_{2} \mathrm{O}$, stirred, filtered through Whatman \#50 filter paper, and analyzed for total $\mathrm{Cu}$ using inductively coupled plasma optical emission spectroscopy (ICP-OES).

Following harvest, soils were removed from pots, air-dried, and ground to pass a 2-mm sieve. Soils were extracted for plant-available $\mathrm{Cu}$ using diethylenetriaminepentaacetic acid (DPTA; Lindsay and Norvell 1978) and for total $\mathrm{Cu}$ with $4 \mathrm{MHNO}_{3}$ (Bradford et al. 1975). All extracts were filtered through Whatman $\# 50$ and analyzed using ICP-OES. The quantity of $\mathrm{Cu}$ accumulated by alfalfa and the DTPA-extractable soil $\mathrm{Cu}$ were compared using linear regression analysis to determine an upper level soil DTPA Cu concentration associated with the National Research Council (2005) maximum tolerable $\mathrm{Cu}$ level in cattle feed.

If necessary, data were $\log _{10}$ transformed to improve normality and reduce heteroscedascity before analysis (Steel and Torrie, 1980). Then, all soil and plant statistical tests were performed using the Proc GLM model in SAS software version 9.1 (SAS Institute 2002). Differences were examined using analysis of variance at a significance level $(p)$ of 0.05 with mean separation determined using Fisher's Protected LSD test.

\subsection{Soil Bacterial Community Analysis}

In addition to collecting a pre-study soil sample, soil subsamples were collected immediately following plant harvest and placed in a $-80^{\circ} \mathrm{C}$ freezer for bacterial community analysis. The pre-study soils consisted of soil devoid of plant and copper additions and all soil subsamples for bacterial analysis were collected from the alfalfa root zone. One replicate of each subsample was selected at random, and deoxyribonucleic acid (DNA) was extracted using a SoilMaster DNA Extraction Kit (Epicentre, Madison, WI), and with an additional DNA purification step using an UltraClean GelSpin DNA Extraction Kit (MO BIO Laboratories, Inc., Carlsbad, CA). The DNA quantity was determined via Biophotometer (Eppendorf AG, Hamburg, Germany), while quality was assessed by electrophoresis on a $1 \%$ agarose gel stained with SYBR Safe (Invitrogen, Carlsbad, CA). Only DNA with a 260/280 ratio between $1.7-1.9$, with a majority of the fragments greater than $5 \mathrm{~kb}$ in size, was used in this study.

Extracted DNA was analyzed by ribosomal intergenic spacer analysis (RISA) using primers ITSF (5' GTCGTAACAAGGTAGCCGTA - 3') and ITSReub (5' - GCCAAGGCATCCACC - 3') to amplify the variable length region between the $16 \mathrm{~S}$ and $23 \mathrm{~S}$ rDNA genes of the soil bacterial populations (Cardinale et al. 2004). Final reaction concentration of reagents were $10 \mathrm{ng}$ of DNA, 1x PCR buffer, $1.5 \mathrm{U}$ of Taq DNA polymerase (New England Biolabs, Ipswich, MA), $0.2 \mathrm{mM}$ of each deoxynucleoside triphosphate, and $0.25 \mu \mathrm{M}$ of each primer in a final volume of $25 \mu \mathrm{l}$. Amplifications were performed at $94^{\circ} \mathrm{C}$ for $3 \mathrm{~min}$, followed by 30 cycles of $94^{\circ} \mathrm{C}$ for $45 \mathrm{~s}, 55^{\circ} \mathrm{C}$ for $1 \mathrm{~min}, 72^{\circ} \mathrm{C}$ for $2 \mathrm{~min}$, with a final extension at $72^{\circ} \mathrm{C}$ for $7 \mathrm{~min}$. A total of $1 \mu 1$ of each amplification reaction was loaded, and RISA fragments were resolved on $3.7 \% \mathrm{~KB}^{\text {Plus }}$ polyacrylamide gels (LI-COR Inc., Lincoln, NE) of $66 \mathrm{~cm}$ length and $0.2 \mathrm{~mm}$ thickness. Profiles were run under denaturing conditions for $15 \mathrm{~h}$ at $3000 \mathrm{~V} / 60 \mathrm{~A}$ on a LiCor 4300 DNA Analyzer (LI-COR Inc., Lincoln, NE). Gel images were analyzed using Phoretix 1D software (Nonlinear Dynamics, Newcastle upon Tyne, United Kingdom). Bands (hereafter referred to as phylotypes) were determined, and matched between soil RISA profiles based on their electrophoretic mobility. 
Soil bacterial diversity was determined from the RISA profiles using the Shannon-Wiener diversity index [H; (Margalef 1958)]. For $H, p_{i}$ was calculated as $p_{i}=n_{i} / N$ with $n_{i}$ representing the peak intensity of individual phylotypes to the $i$ th phylotype in a profile, and $N$ representing the total peak intensity of the profile. Evenness $[(J$; (Pielou 1966)] of the soil RISA profiles was calculated using sample richness $(S)$ which was calculated as the total number of phylotypes for a given profile.

Cluster analysis of soil RISA profiles was performed by the unweighted pair-group method with arithmetic averages (UPGMA), using a Pearson correlation coefficient, via the Phoretix 1D software (Nonlinear Dynamics, Newcastle upon Tyne, United Kingdom).

\section{Results and Discussion}

\subsection{Alfalfa ET, Growth, and Alfalfa Cu Concentration}

Cumulative ET was not affected by increasing $\mathrm{Cu}$ applications up to $100 \mathrm{mg} \mathrm{kg}^{-1}$ for the Declo and Logan soils (Figure 1). However, ET decreased significantly above these $\mathrm{Cu}$ rates, likely because the alfalfa was either stressed or dead. Menon et al. (2005) observed similar results while investigating the effect of topsoil heavy metal contamination on newly established vegetation. The authors placed contaminated topsoil $\left(2700 \mathrm{mg} \mathrm{kg}^{-1} \mathrm{Zn}_{\text {, }}\right.$ $385 \mathrm{mg} \mathrm{kg}^{-1} \mathrm{Cu}, 63 \mathrm{mg} \mathrm{kg}^{-1} \mathrm{~Pb}, 10 \mathrm{mg} \mathrm{kg}^{-1} \mathrm{Cu}$ ) over non-contaminated subsoil seeded with various plants and monitored soil water potential and plant transpiration over several years. Heavy metal contaminated topsoils maintained significantly greater soil water potentials than controls, indicating that less water was lost from the contaminated soil (Menon et al., 2005). The authors also noted a reduction in poplar (Populus tremula) transpiration in metal contaminated soil as compared to controls. Decreases in transpiration due to heavy metal exposure may be explained by decreases in root growth (Pahlsson, 1989), blockages of xylem tissue (Lamoreaux and Chaney, 1977; Robb et al., 1980), or decreased stomatal closure induced by water stress (Schlegel et al., 1987) which could result in reduced growth.

Alfalfa growth was unaffected by $\mathrm{Cu}$ application up to $250 \mathrm{mg} \mathrm{kg}^{-1}$ for the Logan soil while a quadratic growth response was observed for the Declo soil (Table 2). No alfalfa plants survived the 500 and $1000 \mathrm{mg} \mathrm{kg}^{-1} \mathrm{Cu}$ concentrations in both soils, and thus plant $\mathrm{Cu}$ content for these rates are not shown. Similar plant responses have been observed in other studies. Sonmez et al. (2006) applied up to $2000 \mathrm{mg} \mathrm{Cu} \mathrm{kg} \mathrm{soil}{ }^{-1}$ to tomato (Lycopersicon esculentum (L.) Mill. Cv. F144), noting total yield, fruit number, dry root weight, and plant height decreased with increasing application rate. Ginocchio et al. (2006) showed that above $\sim 300 \mathrm{mg} \mathrm{Cu} \mathrm{kg}{ }^{-1} \mathrm{lettuce}$ (Lactuca sativa var. capitata) yield began to decrease. Strandberg et al. (2006) studied Cu-spiked soil effects on growth of Black Bindweed (Fallopia convolvulus), showing that shoot growth was reduced to $50 \%$ at a $\mathrm{Cu}$ application of $280 \mathrm{mg} \mathrm{kg}^{-1}$, and was absent above $400 \mathrm{mg} \mathrm{kg}^{-1}$.

Alfalfa $\mathrm{Cu}$ concentrations increased with increasing $\mathrm{Cu}$ application rate for both soils (Table 2). The $250 \mathrm{mg} \mathrm{kg}^{-1}$ $\mathrm{Cu}$ application rate likely stressed alfalfa more so than the other $\mathrm{Cu}$ rates, thus causing a reduction in ET and/or biomass. Because the $\mathrm{pH}$ of the two soils were similar ( $\mathrm{pH}$ 7.9), differences in plant $\mathrm{Cu}$ concentrations between the two soils were likely due to textural differences associated with clay content, and to quantities of $\mathrm{CaCO}_{3}$ and $\mathrm{OM}$ present which helped form insoluble $\mathrm{Cu}$ precipitates and organic $\mathrm{Cu}$ complexes. The Declo soil is classified as a loam (i.e. less clay) while the Logan soil is a silty clay loam (i.e. more clay). It has been shown that increasing soil clay content causes an increase in Cu sorption (Maftoun et al., 2002; Ghasemi-Fasaei et al., 2006). The Declo and Logan soils also contained 11 and $49 \% \mathrm{CaCO}_{3}$, and 1.2 and $2.5 \% \mathrm{OM}$, respectively (Table 1). Greater quantities of clay, $\mathrm{CaCO}_{3}$, and $\mathrm{OM}$ in the Logan soil, as compared to the Declo soil, likely reacted with more soluble $\mathrm{Cu}$ and made $\mathrm{Cu}$ less available for alfalfa uptake. And, as $\mathrm{Cu}$ rate increased, $\mathrm{Cu}$ likely overwhelmed soil sorption sites which led to greater $\mathrm{Cu}$ availability and detrimental plant effects.

Soil clays, $\mathrm{CaCO}_{3}$, and $\mathrm{OM}$ influence $\mathrm{Cu}$ sorption, however, in soils with $\mathrm{pH}$ values greater than 7.0 soluble $\mathrm{Cu}$ has been shown to react and form $\mathrm{CuO}, \mathrm{CuCO}_{3}, \mathrm{Cu}_{2}(\mathrm{OH})_{2} \mathrm{CO}_{3}$ (malachite), and $\mathrm{Cu}(\mathrm{OH})_{2}$ (McBride and Bouldin, 1984; Ponizovsky et al., 2007; Ma et al., 2006). Rodriguez-Rubio et al. (2003) showed that $\mathrm{Cu}$ sorption on calcareous soils was enhanced by addition of calcite and $\mathrm{OM}$, but $\mathrm{Cu}$ sorption decreased with the removal of the soil carbonate fraction. The authors suggested $\mathrm{CuO}, \mathrm{Cu}(\mathrm{OH})_{2}$, and malachite were controlling $\mathrm{Cu}$ availability. McBride and Bouldin (1984) found evidence of malachite precipitation in a $\mathrm{Cu}$ contaminated calcareous soil, yet the soil contained $5.3 \% \mathrm{OM}$ and greater than $95.5 \%$ of the $\mathrm{Cu}$ in soil solution was complexed with organic species. Maftoun et al. (2002) concluded that $\mathrm{Cu}$ retention in calcareous soils was related to $\mathrm{CaCO}_{3}$ and $\mathrm{OM}$, yet McBride and Blasiak (1979) suggested that the majority of $\mathrm{Cu}$ is strongly adsorbed to OM in calcareous soils due to both greater OM solubility and greater $\mathrm{pH}$ dependent charge present. When present in calcareous soils, it has been shown that increasing OM content ( 0.4 to $4.8 \%$; within the range of our study) decreases the quantity of plant-available $\mathrm{Cu}$ (Ghasemi-Fasaei et al., 2006) due to $\mathrm{Cu}$ complexation with organic species. Between 80 and 
$100 \%$ of $\mathrm{Cu}$ added to neutral or calcareous soils has been shown to be organically complexed (Cavallaro and McBride, 1978; McBride and Blasiak, 1979).

\subsection{Soil Total and DTPA-Extractable $\mathrm{Cu}$, and Associated Alfalfa $\mathrm{Cu}$ Content}

Soil total and DTPA-extractable $\mathrm{Cu}$ content increased with increasing $\mathrm{Cu}$ application rate (Table 3), as was expected. Between 48 to $67 \%$ of the total $\mathrm{Cu}$ measured in the Declo soil was plant-available as determined by the DTPA extraction, while 70 to $80 \%$ was plant-available in the Logan soil. The remainder of $\mathrm{Cu}$ was likely sorbed to OM or precipitated as inorganic phases, as previously outlined. Other research has shown lower DTPA-extractable $\mathrm{Cu}$ concentrations after short incubation times. Ghasemi-Fasaei et al. (2006) demonstrated that after 20 days of incubation, DTPA extracted only $20 \%$ of the total soluble $\mathrm{Cu}\left(5 \mathrm{mg} \mathrm{kg}^{-1}\right)$ added to calcareous soils. Greater $\mathrm{Cu}$ rates in the current study likely saturated soil sorption sites, and thus more $\mathrm{Cu}$ remained available as compared to that found by Ghasemi-Fasaei et al. (2006).

Soil DTPA-extractable $\mathrm{Cu}$ was used to determine an estimate of extractable soil $\mathrm{Cu}$ associated with alfalfa copper content and the maximum tolerable $\mathrm{Cu}$ level in cattle feed $\left(40 \mathrm{mg} \mathrm{kg}^{-1}\right)$ based on National Research Council (2005) guidelines (Fig. 2). A first order polynomial equation fit the observed Declo and Logan well (both $\mathrm{R}^{2}=0.977$; dashed lines Fig. 2). Based on the predicted fit for the Declo soil, $63 \mathrm{mg} \mathrm{kg}{ }^{-1}$ of DTPA-extractable soil $\mathrm{Cu}$ would produce a $40 \mathrm{mg} \mathrm{Cu} \mathrm{kg}{ }^{-1}$ alfalfa response and be detrimental to cattle. Following the same approach for the Logan soil, $95 \mathrm{mg} \mathrm{kg}^{-1}$ of DTPA-extractable soil Cu would be detrimental to cattle health. Greater soil DTPA extractable $\mathrm{Cu}$ can be tolerated in the Logan soil due to the aforementioned influence of increased clay, $\mathrm{CaCO}_{3}$, and $\mathrm{OM}$ content. These values can be used as an estimate for determining soil DTPA $\mathrm{Cu}$ concentrations associated with alfalfa $\mathrm{Cu}$ concentration cattle feeding risk.

Stehouwer and Roth (2009) suggested that if copper was added gradually to soil $\left(<11 \mathrm{~kg} \mathrm{ha}^{-1} \mathrm{yr}^{-1}\right.$; which is not uncommon (Rankin, 2008)) then approximately $170 \mathrm{~kg} \mathrm{ha}^{-1}$ could be added to light textured, low OM soils (< $1 \%$; Stehouwer, personal communication) without causing crop toxicity. Heavier textured soils with moderate to high $\mathrm{OM}$ contents could receive three to five times as much $\mathrm{Cu}$ without experiencing crop toxicity symptoms (Stehouwer and Roth, 2009). However, Klingberg (2009) recommended that continued use of high copper content manures on the same field over many years should be avoided because of the potential for crop toxicity.

The Declo soil series is light textured (loam) with low OM content (1.2\%; Table 1). Alfalfa grown on these soils requires on average $40 \mathrm{ha} \mathrm{cm}$ of irrigation water (US Department of Interior, 2009). Total $\mathrm{Cu}$ from south central Idaho dairy lagoon effluent was recently measured at $35.4 \mathrm{mg} \mathrm{L}^{-1}$ (D. Tarkalson, personal communication). Assuming 5\% Cu availability (Stehouwer and Roth, 2009) in the effluent and if effluent water were solely used to irrigate alfalfa, a total of $17.5 \mathrm{~kg} \mathrm{Cu} \mathrm{ha}^{-1} \mathrm{yr}^{-1}$ would be applied to Declo soils. Assuming $170 \mathrm{~kg}$ of plant-available $\mathrm{Cu} \mathrm{ha}{ }^{-1}$ could be added before crop toxicity was observed, approximately 10 years would be required to reach this $\mathrm{Cu}$ level. One should keep in mind that this calculation does not account for crop removal or potential changes in soil $\mathrm{Cu}$ availability which would lengthen the time until crop toxicity is observed. In the case of the Logan soil, it is heavier textured (silty clay loam) and contains twice as much OM as the Declo soil, and thus could possibly receive greater $\mathrm{Cu}$ quantities before experiencing crop toxicity symptoms.

\subsection{Effect of copper sulfate on soil bacterial community diversity}

To assess the impact of copper sulfate concentrations on the soil bacterial communities, we examined the bacterial RISA profiles of two different soil series growing alfalfa under varying copper treatment regimens. The UPGMA clustering analysis of the bacterial RISA profiles of both the Declo (Figure 3) and Logan (Figure 4) soil series divided the $\mathrm{Cu}$ treated soils into two clusters. For the Declo soils, the first and second clusters consisted of the 0 and $50 \mathrm{mg} \mathrm{kg}^{-1}$ (73\% similarity) and 100, 250, 500, and $1000 \mathrm{mg} \mathrm{kg}^{-1}$ (69\% similarity) $\mathrm{Cu}$ application treatments, respectively. Together, the two clusters had a $65 \%$ similarity, with $59 \%$ similarity to the pre-study sample. For the Logan soils, the first cluster included the pre-study sample along with the 0,50 , and $100 \mathrm{mg} \mathrm{kg}^{-1}$ (66\% similarity) $\mathrm{Cu}$ application treatments; the second cluster consisted of the 250,500 , and $1000 \mathrm{mg} \mathrm{kg}^{-1}(65 \%$ similarity) $\mathrm{Cu}$ application treatments and had $61 \%$ similarity to the first cluster. The differences in similarity between the soils receiving $\mathrm{Cu}$ application could not be attributed solely to loss of bands in profiles receiving larger dosages of $\mathrm{Cu}$, as the richness (S) of the profiles remained consistent between the treatments (Table 4); on average, Declo soils had $62.8 \pm 2.1$ bands per profile and Logan soils had $76.5 \pm 3.1$ bands per profile.

Based on the bacterial RISA profiles, Shannon-Weiner diversity indices and the corresponding evenness values were calculated (Table 4). For the Declo soil series, $H$ remained stable with a decrease in overall diversity between soils with no copper application $(H=3.88)$ and $1000 \mathrm{mg} \mathrm{Cu} \mathrm{kg}^{-1}(H=3.81)$. For the Logan soil series, $H$ demonstrated an increase at $50 \mathrm{mg} \mathrm{kg}^{-1}$ before trending downward until $1000 \mathrm{mg} \mathrm{kg}^{-1}$. Evenness $(J)$ remained high $(J>0.875)$ for all treatments, indicating no individual species dominated any of the $\mathrm{Cu}$ treatments. The 
pattern of bacterial diversity in the Logan soils was similar to a study by Zhang et al. (2009) who researched bacterial diversity in response to $\mathrm{Cd}$, another heavy metal known to stress bacterial populations; both the Logan soils and the soils studied by Zhang et al. (2009) revealed a peak in bacterial diversity at the lower concentrations of heavy metal contamination, a response also previously detailed by Giller et al. (1998). For the Logan soils, this increase in diversity could have been in response to either increased levels of $\mathrm{Cu}$ bioavailability (Ranjard et al., 2006), or environmental stress (Huysman et al., 1994). In comparison to the Logan soils, the Declo soils demonstrated a different response to $\mathrm{Cu}$ concentrations. Rather than peak at low levels of contamination, the diversity remained relatively stable regardless of the $\mathrm{Cu}$ concentration; however, there was an increase in diversity over the pre-study soils $(H=3.74)$ upon the planting of alfalfa $(H=3.88)$. This result runs counter to studies which have reported decreasing microbial diversity under high concentrations of heavy metals (Giller et al., 1998). However, our results are supported by Zhang et al. (2009) who also observed little effect on the structure and diversity of soil bacterial communities under long-term Cd stress. The researchers attributed this to the heterogeneity of soils, and how impacts upon bacterial community structure and diversity by heavy metals could be countered by other soil characteristics such as total organic carbon, total nitrogen, and nutrient status. Indeed, a report by Speir et al. (1999) indicated that soil acidification played a significant role in reducing microbial enzymatic activity; this inhibition could be directly attributed to acidification rather than the introduction of heavy metals into the soil profile. In the current study, $\mathrm{pH}$ remained stable for both the Declo $(\mathrm{pH}$ $8.10 \pm 0.2)$ and Logan $(\mathrm{pH} 7.9 \pm 0.2)$ soils with neither representing an acidic environment, likely attributed to the high $\mathrm{CaCO}_{3}$ content in both soil series.

\section{Conclusions}

The objectives of this investigation were to identify $\mathrm{Cu}$ application effects on alfalfa growth and $\mathrm{Cu}$ concentration, total and DTPA-extractable soil $\mathrm{Cu}$ content, and the soil bacterial community. In addition, soil DTPA-extractable $\mathrm{Cu}$ was used to determine an estimate of extractable soil $\mathrm{Cu}$ associated with alfalfa copper content and the maximum tolerable $\mathrm{Cu}$ level in cattle feed based on National Research Council (2005) guidelines.

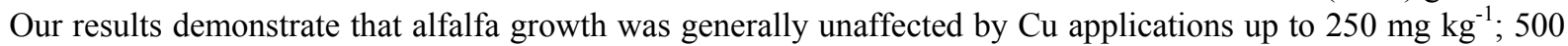
and $1000 \mathrm{mg} \mathrm{kg}^{-1} \mathrm{Cu}$ application rates killed alfalfa. Although increasing $\mathrm{Cu}$ application rates caused an increase in alfalfa $\mathrm{Cu}$ content, only $\mathrm{Cu}$ application rates greater than $250 \mathrm{mg} \mathrm{kg}^{-1}$ decreased ET in both soils. The DTPA-extractable $\mathrm{Cu}$ content increased with increasing $\mathrm{Cu}$ application, and following 23 days since $\mathrm{Cu}$ application 48 to $80 \%$ of the added $\mathrm{Cu}$ was still plant-available. Above 63 and $95 \mathrm{mg} \mathrm{kg}^{-1}$ of DTPA-extractable soil $\mathrm{Cu}$ was associated with the maximum dietary alfalfa $\mathrm{Cu}$ limit $\left(40 \mathrm{mg} \mathrm{kg}^{-1}\right)$ for cattle in Declo and Logan soil, respectively. Bacterial community analysis revealed that soils clustered according to low and high $\mathrm{Cu}$ application rates. For the Logan soils, bacterial diversity peaked at $50 \mathrm{mg} \mathrm{kg}^{-1}$ while Declo soil bacterial diversity remained relatively stable throughout the entire course of $\mathrm{Cu}$ applications. These differences could potentially be explained by differences in the characteristics of the individual soil series.

Based on the predicted DTPA-extractable soil $\mathrm{Cu}$ to detrimental animal dietary consumption values, it is suggested that plant-available soil $\mathrm{Cu}$ concentrations not exceed $63 \mathrm{mg} \mathrm{kg}^{-1}$ in these agroecosystems. In regards to bacterial community structure and diversity, our analysis indicates that the effects of $\mathrm{Cu}$ application rates are most likely soil series dependent, but that generally the bacterial communities are able to withstand higher rates of $\mathrm{Cu}$ in their environment. Most states do not have environmental regulations in place regarding $\mathrm{Cu}$ handling and land application. However, as with any land application of waste program it is suggested that soil testing is conducted on a routine basis to ensure optimum crop yields along with environmental protection.

\section{References}

Adriano, D. C. (1986). Copper. In D.C. Adriano (Ed.), Trace elements in the terrestrial environment (pp. 181-218). New York, NY: Springer-Verlag.

Bradford, G. R., Page, A. L., Lund, L. J., \& Olmstead, W. (1975). Trace element concentrations of sewage treatment plant effluents and sludges: their interactions with soil and uptake by plants. Journal of Environmental Quality, 4, 123-127.

Brun, L. A., Maillet, J., Hinsinger, P., \& Pepin, M. (2001). Evaluation of copper availability to plants in copper-contaminated vineyard soils. Environmental Pollution, 111, 293-302.

Cardinale, M., Brusetti, L., Quatrini, P., Borin, S., Puglia, A. M., Rizzi, A., Zanardini, E., Sorlini, C., Corselli, C., $\&$ Daffonchio, D. (2004). Comparison of different primer sets for use in automated ribosomal intergenic spacer analysis of complex bacterial communities. Applied Environmental Microbiology, 70, 6147-56. 
Cavallaro, N., \& McBride, M. B. (1978). Copper and cadmium adsorption characteristics of selected acid and calcareous soils. Soil Science Society of America Journal, 42, 550-556.

Gee, G. W., \& or, D. (2002). Particle-size analysis. In J. H. Dane, \& G. C. Topp (Eds.). Methods of Soil Analysis, Part 4 - Physical Methods (pp. 255-293). Madison, WI: Soil Science Society of America.

Ghasemi-Fasaei, R., Maftoun, M., Ronaghi, A., Karimian, N., Yasrebi, J., Assad, M. T., \& Ippolito, J. (2006). Kinetics of Copper Desorption from Highly Calcareous Soils. Communications in Soil Science and Plant Analysis, 37, 797-809.

Giller, K. E., Witter, E., \& McGrath, S. P. (1998). Toxicity of heavy metals to microorganisms and microbial processes in agricultural soils: A review. Soil Biology and Biochemistry, 30, 1389-1414.

Ginocchio, R., Sanchez, P., de la Fuente, L. M., Camus, I., Bustamante, E., Silva, Y., Urrestarazu, P., Torres, J. C., \& Rodriguez, P. H. (2006). Agricultural soils spiked with copper mine wastes and copper concentrate: Implications for copper bioavailability and bioaccumulation. Environmental Toxicology and Chemistry, 25, $712-718$.

Huysman, F., Verstraete, W., \& Brookes, P. C. (1994). Effect of manuring practices and increased copper concentrations on soil microbial populations. Soil Biology and Biochemistry, 26, 103-110.

Klingberg, K. (2009). Copper sulfate foot bath treatment for animal health: Impact on manure nutrient content, crops, soil and the environment. [Online] Available: http://www.docstoc.com/docs/23141497/Copper-Sulfate-Foot-Bath-Treatment-for-Animal-Health-Impact (October 21, 2010).

Kuo, S. (1996). Phosphorus. In D. L. Sparks (Ed.), Methods of Soil Analysis, Part 3 - Chemical Methods (pp. 894-897). Madison, WI: Soil Science Society of America.

Lamoreaux, R. J., \& Chaney, W. R. (1977). Growth and water movement in silver maple seedlings affected by cadmium. Journal of Environmental Quality, 6, 201-205.

Lindsay, W. L., \& Norvell, W. A. (1978). Development of a DTPA soil test for zinc, iron, manganese, and copper. Soil Science Society of America Journal, 42, 421-428.

Ma, Y., Lombi, E., Oliver, I. W., Nolan, A. L., \& McLaughlin, M. J. (2006). Long-term aging of copper added to soils. Environmental Science and Technology, 40, 6310-6317.

Maftoun, M., Karimian, N., \& Moshiri, F. (2002). Sorption characteristics of copper(II) in selected calcareous soils of Iran in relation to soil properties. Communications in Soil Science and Plant Analysis, 33, 2279-2289.

Margalef, R. (1958). Information theory in ecology. General Systems, 3, 36-71.

McBride, M. B., \& Blasiak, J. J. (1979). Zinc and copper solubility as a function of $\mathrm{pH}$ in an acid soil. Soil Science Society of America Journal, 43, 866-870.

McBride, M. B., \& Bouldin D. R. (1984). Long-term reactions of copper(II) in a contaminated calcareous soil. Soil Science Society of America Journal, 48, 56-59.

Menon, M., Hermle, S., Abbaspour, K. C., Gunthardt-Goerg, M. S., Oswald, S. E., \& Schulin, R. (2005). Water regime of metal-contaminated soil under juvenile forest vegetation. Plant and Soil, 271, 227-241.

Mulvaney, R. L. (1996). Nitrogen - inorganic forms. In D. L. Sparks (Ed.), Methods of Soil Analysis, Part 3 Chemical Methods (pp. 1123-1184). Madison, WI: Soil Science Society of America.

National Research Council. (2005). Mineral tolerance of animals. $2^{\text {nd }}$ revised edition. Washington, DC: The National Academies Press.

Nelson, D. W., \& Sommers, L. E. (1996). Total carbon, organic carbon, and organic matter. In D. L. Sparks (Ed.), Methods of Soil Analysis, Part 3 - Chemical Methods (pp. 975-977). Madison, WI: Soil Science Society of America.

Pahlsson, A.B. (1989). Toxicity of heavy metals $(\mathrm{Zn}, \mathrm{Cu}, \mathrm{Cd}, \mathrm{Pb})$ to vascular plants: A literature review. Water Air and Soil Pollution, 47, 287-319.

Paschke, M. W., \& Redente, E. F. (2002). Copper toxicity thresholds for important restoration grass species of the western United States. Environmental Toxicology and Chemistry, 21, 2692-2697.

Pielou, E.C. (1966). The measurement of diversity in different types of biological collections. Journal of Theoretical Biology, 13, 131-144. 
Pierzynski, G. M., Sims, J. T., \& Vance, G. F. (2000). Soils and environmental quality (p. 459). Boca Raton, FL: CRC Press.

Ponizovsky, A. A., Allen, H. E., \& Ackerman, A. J. (2007). Copper activity in soil solutions of calcareous soils. Environmental Pollution, 145, 1-6.

Ranjard, L., Echairi, A., Nowak, V., Lejon, D. P. H., Nouaim, R., \& Chaussod, R. (2006). Field and microcosm experiments to evaluate the effects of agricultural $\mathrm{Cu}$ treatment on the density and genetic structure of microbial communities in two different soils. FEMS Microbiology Ecology, 58, 303-315.

Rankin, M. (2008). Agronomic and environmental issues with foot bath solution land spreading. [Online] Available: http://www.uwex.edu/ces/crops/4StateCopper.pdf. (October 21, 2010).

Rhoades, J. D. (1996). Salinity: Electrical conductivity and total dissolved solids. In D. L. Sparks (Ed.), Methods of Soil Analysis, Part 3 - Chemical Methods (pp. 417-435). Madison, WI: Soil Science Society of America.

Robb, J., Busch, L., \& Rauser, W. E. (1980). Zinc toxicity and xylem vessel wall alterations in white beans. Annals of Botany, 46, 43-50.

Rodriguez-Rubio, P., Morillo, E., Madrid, L., Undabeytia, T., \& Maqueda, C. (2003). Retention of copper by a calcareous soil and its textural fractions: influence of amendment with two agroindustrial residues. European Journal of Soil Science, 54, 401-409.

SAS Institute. (2002). SAS/STAT user's guide. Version 9.1. Cary, NC: SAS Inst.

Sauve, S. (2006). Copper inhibition of soil organic matter decomposition in a seventy-year field exposure. Environmental Toxicology and Chemistry, 25, 854-857.

Schlegel, H., Godbold, D. L., \& Huttermann, A. (1987). Whole plant aspects of heavy metal induced changes in CO2 uptake and water relations of spruce (Picea abies) seedlings. Physiologia Plantarum, 69, 265-270.

Sherrod, L. A., Dunn, G., Peterson, G. A., \& Kolberg, R. L. (2002). Inorganic carbon analysis by modified pressure-calcimeter method. Soil Science Society of America Journal, 66, 299-305.

Sonmez, S., Kaplan, M., Sonmez, N. K., Kaya, H., \& Uz, I. (2006). High level of copper application to soil and leaves reduce the growth and yield of tomato plants. Scientia Agricola, 63, 213-218.

Speir, T. W., Kettles, H. A., Percival, H. J., \& Parshotam, A. (1999). Is soil acidification the cause of biochemical responses when soils are amended with heavy metal salts? Soil Biology and Biochemistry, 31, 1953-1961.

Stark, J., Brown, B., \& Shewmaker, G. (2002). Southern Idaho Fertilizer Guide. Irrigated alfalfa. Current Information Series No. 1102. University of Idaho Extension and Agricultural Experiment Station.

Steel, R. G. D., \& Torrie, J. H. (1980). Principles and procedures of statistics: A biometrical approach. 2nd

Edition. New York, NY: McGraw-Hill.

Stehouwer, R., \& Roth, G. (2009). Copper sulfate hoof baths and copper toxicity in soil. [Online] Available: http://www.das.psu.edu/news/dd200403-03. (October 21, 2010).

Strandberg, B., Axelsen, J. A., Pedersen, M. B., Jensen, J., \& Attrill, M. J. (2006). Effect of copper gradient on plant community structure. Environmental Toxicology and Chemistry, 25, 743-753.

Sumner, M. E., \& Miller, W. P. (1996). Cation exchange capacity and exchange coefficients. In D. L. Sparks (Ed.), Methods of Soil Analysis, Part 3 - Chemical Methods (pp. 1201-1229). Madison, WI: Soil Science Society of America.

Thomas, G. W. (1996). Soil pH and soil acidity. In D. L. Sparks (Ed.), Methods of Soil Analysis, Part 3 Chemical Methods (pp. 475-490). Madison, WI: Soil Science Society of America.

US Department of Interior. (2009). Agrimet, The Pacific Northwest Cooperative Agricultural Weather Network. [Online] Available: http://www.usbr.gov/pn/agrimet/ETtotals.html (October 21, 2010).

USDA National Agricultural Statistics Service. (2009). U.S. \& all states data - Dairy milk production, milk cows, milk per cow: annual. [Online] Available: http://www.nass.usda.gov/Data_and_Statistics/Quick_Stats/ (October 21, 2010).

USDA National Resource Conservation Service. (2009). Web soil survey. [Online] Available: http://websoilsurvey.nrcs.usda.gov/app/ (October 21, 2010). 
White, P. J., \& Brown, P. H. (2010). Plant nutrition for sustainable development and global health. Annals of Botany, 105, 1073-1080.

Zhang, Y., Zhang, X., Zhang, H., He, Q., Zhou, Q., Su, Z., \& Zhang, C. (2009). Responses of soil bacteria to long-term and short-term cadmium stress as revealed by microbial community analysis. Bulletin of Environmental Contamination and Toxicology, 82, 367-372.

Table 1. Certain properties of the Declo and Logan soil series prior to $\mathrm{Cu}$ application

\begin{tabular}{|l|c|c|c|}
\hline Property & Units & Declo Soil Series & Logan Soil Series \\
\hline Texture & & loam & silty clay loam \\
\hline $\mathrm{pH}$ & & 7.9 & 7.9 \\
\hline $\mathrm{EC}$ & $\mathrm{dS} \mathrm{m}^{-1}$ & 1.02 & 0.73 \\
\hline $\mathrm{CEC}$ & $\mathrm{cmol}_{\mathrm{c} \mathrm{kg}}$ & 14 & 14 \\
\hline Total C & $\mathrm{g} \mathrm{kg}^{-1}$ & 20 & 73 \\
\hline CaCO & $\mathrm{g} \mathrm{kg}^{-1}$ & 110 & 490 \\
\hline Inorganic C & $\mathrm{g} \mathrm{kg}^{-1}$ & 13 & 59 \\
\hline Organic C & $\mathrm{g} \mathrm{kg}^{-1}$ & 7.0 & 14 \\
\hline Organic Matter & $\mathrm{g} \mathrm{kg}^{-1}$ & 12 & 25 \\
\hline $\mathrm{NO}_{3}-\mathrm{N}$ & $\mathrm{mg} \mathrm{kg}^{-1}$ & 11.6 & 9.82 \\
\hline $\mathrm{NH}_{4}-\mathrm{N}$ & $\mathrm{mg} \mathrm{kg}^{-1}$ & 5.20 & 4.75 \\
\hline Olsen $\mathrm{P}$ & $\mathrm{mg} \mathrm{kg}^{-1}$ & 13 & 19 \\
\hline Total Ca & $\mathrm{mg} \mathrm{kg}^{-1}$ & 30560 & 85600 \\
\hline Total Mg & $\mathrm{mg} \mathrm{kg}^{-1}$ & 6180 & 29800 \\
\hline Total $\mathrm{Na}$ & $\mathrm{mg} \mathrm{kg}^{-1}$ & 398 & 414 \\
\hline Total K & $\mathrm{mg} \mathrm{kg}^{-1}$ & 1430 & 866 \\
\hline Total $\mathrm{Fe}$ & $\mathrm{mg} \mathrm{kg}^{-1}$ & 3290 & 1150 \\
\hline Total P & $\mathrm{mg} \mathrm{kg}^{-1}$ & 706 & 405 \\
\hline Total Mn & $\mathrm{mg} \mathrm{kg}^{-1}$ & 252 & 291 \\
\hline Total $\mathrm{Zn}$ & $\mathrm{mg} \mathrm{kg}^{-1}$ & 27.2 & 27.0 \\
\hline Total Mo & $\mathrm{mg} \mathrm{kg}^{-1}$ & $\mathrm{ND}$ & $\mathrm{ND}$ \\
\hline Total $\mathrm{Cu}$ & $\mathrm{mg} \mathrm{kg}^{-1}$ & 6.52 & 5.04 \\
\hline
\end{tabular}

Table 2. Influence of copper application on alfalfa (Medicago sativa) growth and copper concentration in the Declo and Logan soil series

\begin{tabular}{|c|c|c|c|c|}
\hline & \multicolumn{2}{|c|}{ Declo Soil Series } & \multicolumn{2}{|c|}{ Logan Soil Series } \\
\hline $\begin{array}{c}\mathrm{Cu} \\
\text { Application }\end{array}$ & $\begin{array}{l}\text { Alfalfa } \\
\text { Growth }\end{array}$ & Alfalfa $\mathrm{Cu}$ Concentration & $\begin{array}{l}\text { Alfalfa } \\
\text { Growth }\end{array}$ & Alfalfa $\mathrm{Cu}$ Concentration \\
\hline$\left(\mathrm{mg} \mathrm{kg}^{-1}\right)^{\dagger}$ & $\left(\mathrm{gpot}^{-1}\right)$ & $\left(\mathrm{mg} \mathrm{kg}^{-1}\right)$ & $\left(\mathrm{g} \mathrm{pot}^{-1}\right)$ & $\left(\mathrm{mg} \mathrm{kg}^{-1}\right)$ \\
\hline 0 & $2.82(0.57) \mathrm{a}^{+}$ & $12.7(1.2) \mathrm{a}$ & $4.28(0.65) \mathrm{a}$ & $11.2(2.0) \mathrm{a}$ \\
\hline 50 & $3.22(0.45) \mathrm{ab}$ & $28.4(11.4) \mathrm{b}$ & $4.02(0.33) \mathrm{a}$ & $17.0(1.6) \mathrm{b}$ \\
\hline 100 & $3.05(0.52) \mathrm{a}$ & $47.9(13.2) \mathrm{c}$ & $3.80(0.58) \mathrm{a}$ & $31.9(9.9) \mathrm{c}$ \\
\hline 250 & $2.10(0.78) b$ & $79.0(11.0) \mathrm{d}$ & $3.45(0.95) \mathrm{a}$ & $74.7(27.1) \mathrm{d}$ \\
\hline
\end{tabular}

${ }^{\dagger}$ The 500 and $1000 \mathrm{mg} \mathrm{kg}^{-1} \mathrm{Cu}$ applications were not included in the statistical analysis because no plants survived.

*Values within parentheses represent one standard error of the mean. Different lower case letters within a column indicate significant difference between copper application rates (Fisher's LSD, $p=0.05, \mathrm{n}=4$ ). 
Table 3. Influence of copper application on total and DTPA-extractable copper in the Declo and Logan soil series

\begin{tabular}{|c|c|c|c|c|}
\hline & \multicolumn{2}{|c|}{ Declo Soil Series } & \multicolumn{2}{|c|}{ Logan Soil Series } \\
\hline $\mathrm{Cu}$ Application & Total $\mathrm{Cu}$ & DTPA Cu & Total $\mathrm{Cu}$ & DTPA Cu \\
\hline$\left(\mathrm{mg} \mathrm{kg}^{-1}\right)$ & --- & $--\mathrm{m}$ & -1 & \\
\hline 0 & $7.74(0.10) \mathrm{a}^{+}$ & $0.97(0.05) \mathrm{a}$ & $3.81(0.11) \mathrm{a}$ & $0.67(0.04) \mathrm{a}$ \\
\hline 50 & $62.8(7.83) \mathrm{b}$ & $30.2(4.27) \mathrm{b}$ & $46.6(4.76) \mathrm{b}$ & $32.5(2.26) \mathrm{b}$ \\
\hline 100 & $115(22.5) \mathrm{c}$ & $67.6(13.5) \mathrm{c}$ & $110(7.87) \mathrm{c}$ & $87.2(6.71) \mathrm{c}$ \\
\hline 250 & $272(6.60) \mathrm{d}$ & $175(22.3) d$ & $232(27.6) \mathrm{d}$ & $186(26.2) d$ \\
\hline 500 & $468(63.5) \mathrm{e}$ & $289(39.1) \mathrm{e}$ & $410(164) \mathrm{e}$ & $286(101) \mathrm{e}$ \\
\hline 1000 & $957(17.4) \mathrm{f}$ & $640(18.6) \mathrm{f}$ & $845(79.8) \mathrm{f}$ & $640(50.6) \mathrm{f}$ \\
\hline
\end{tabular}

* Values within parentheses represent one standard error of the mean. Different lower case letters within a column indicate significant difference between copper application rates (Fisher's LSD, $p=0.05, \mathrm{n}=4$ ).

Table 4. Bacterial diversity indices as affected by alfalfa (Medicago sativa) and copper application to the Declo and Logan soil series

\begin{tabular}{|c|c|c|c|c|c|}
\hline Soil Series & Plant & $\begin{array}{c}\text { Cu Application } \\
\left(\mathrm{mg} \mathrm{kg}^{-1}\right)\end{array}$ & $S$ & $H$ & $J$ \\
\hline Declo & None & 0 & 74 & 3.74 & 0.8763 \\
\hline Declo & M. sativa & 0 & 65 & 3.88 & 0.8737 \\
\hline Declo & M. sativa & 50 & 61 & 3.87 & 0.8808 \\
\hline Declo & M. sativa & 100 & 62 & 3.83 & 0.8818 \\
\hline Declo & M. sativa & 250 & 65 & 3.85 & 0.8918 \\
\hline Declo & M. sativa & 500 & 64 & 3.82 & 0.9120 \\
\hline Declo & M. sativa & 1000 & 60 & 3.81 & 0.9099 \\
\hline Logan & None & 0 & 78 & 4.04 & 0.9275 \\
\hline Logan & M. sativa & 0 & 81 & 4.02 & 0.9040 \\
\hline Logan & M. sativa & 50 & 79 & 4.22 & 0.9609 \\
\hline Logan & M. sativa & 100 & 77 & 4.04 & 0.9299 \\
\hline Logan & $M$. sativa & 250 & 75 & 3.91 & 0.9061 \\
\hline Logan & M. sativa & 500 & 73 & 3.92 & 0.9387 \\
\hline Logan & $M$. sativa & 1000 & 74 & 4.01 & 0.9319 \\
\hline
\end{tabular}

$\mathrm{S}=$ Sample Richness; $\mathrm{H}$ = Shannon-Wiener Diversity Index; $\mathrm{J}$ = Evenness.

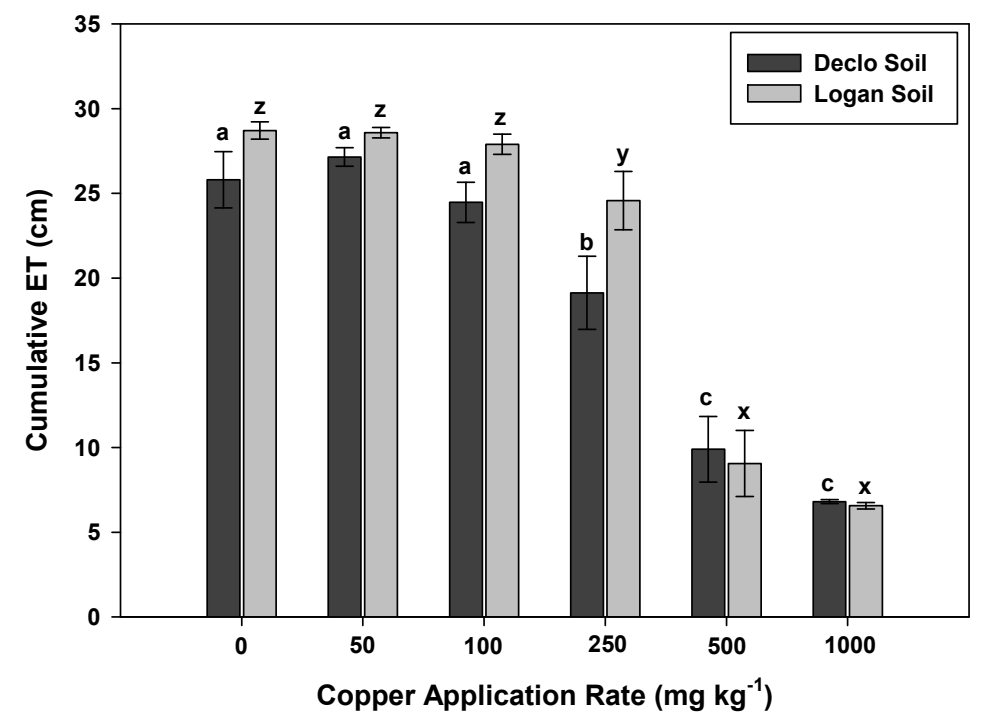

Figure 1. Cumulative alfalfa evapotranspirational (ET) losses for the Declo and Logan soils for the 14 days following copper application (mean +/- SE). Different letters above the bars for either the Declo or Logan soils indicate a significant difference in ET between copper application rates (Fisher's LSD, $p=0.05, \mathrm{n}=4$ ) 


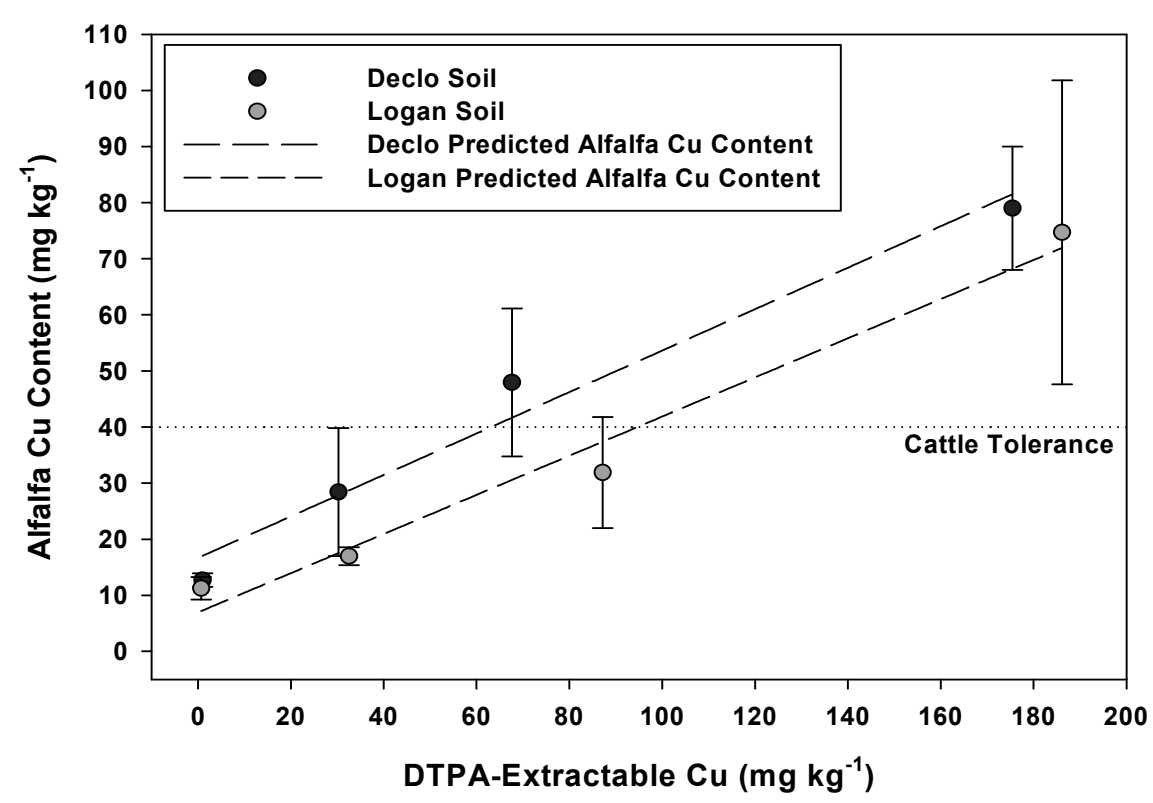

Figure 2. Alfalfa copper concentration versus DTPA-extractable soil copper concentration (mean $+/$ SE). Dashed lines represent the predicted alfalfa copper concentration as compared to either Declo or Logan DTPA-extractable $\mathrm{Cu}$ content. The solid horizontal line represents cattle $\left(40 \mathrm{mg} \mathrm{kg}^{-1}\right)$ maximum tolerable dietary $\mathrm{Cu}$ content based on National Research Council (2005) recommendations

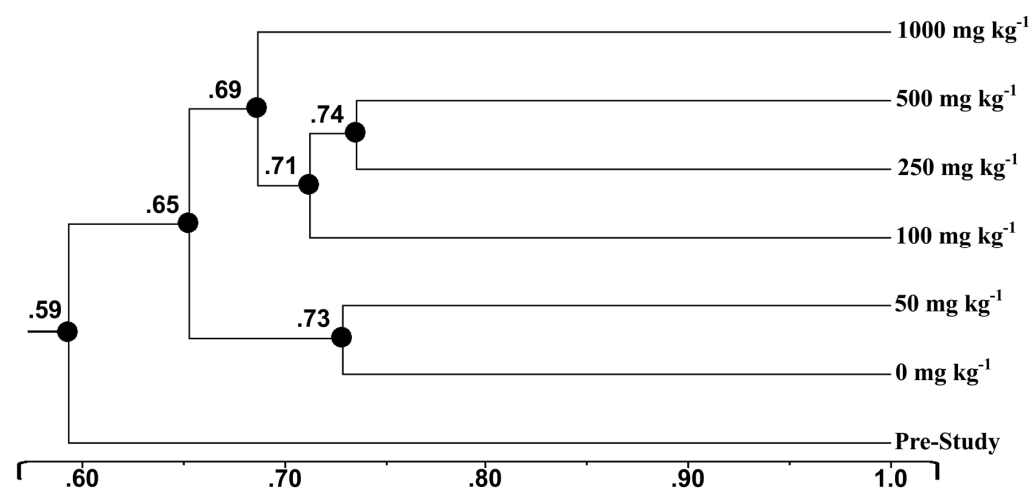

Figure 3. UPGMA dendrogram representing the similarity of bacterial RISA profiles from Declo soil with increasing $\mathrm{Cu}$ application rates. The percentages of similarity amongst the RISA profiles were calculated using the Pearson coefficient. Each profile represents one subsample of each treatment chosen at random

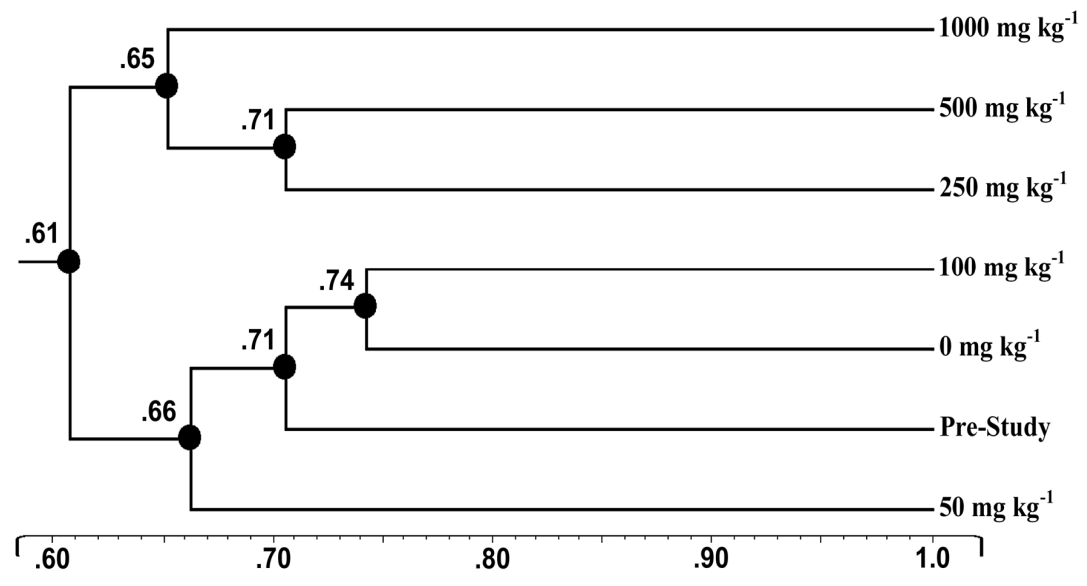

Figure 4. UPGMA dendrogram representing the similarity of bacterial RISA profiles from Logan soil with increasing $\mathrm{Cu}$ application rates. The percentages of similarity amongst the RISA profiles were calculated using the Pearson coefficient. Each profile represents one subsample of each treatment chosen at random 